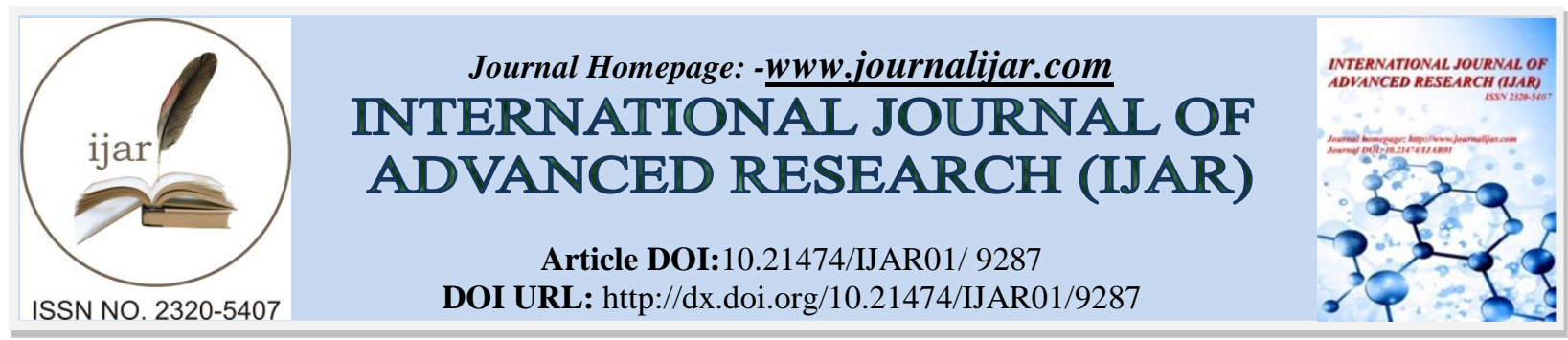

RESEARCH ARTICLE

\title{
POLITICAL PARTICIPATION OF WOMEN IN URBAN LOCAL SELF GOVERNANCE.
}

\section{Shashi kiran shetty and Dr. Kodandarama.}

1. Assistant Professor\& Head, Dept. Of Social Work, Acharya Institute of Graduate Studies \& Research Scholar, Bangalore University .

2. Professor \& Research Guide, Department of Social Work, Bangalore University.

\section{Manuscript Info}

Manuscript History

Received: 15 April 2019

Final Accepted: 17 May 2019

Published: June 2019

Key words:-

Women; Decision making; Political participation, Urban Local Bodies.

\begin{abstract}
Women's political participation plays an important role in establishing the status of women in any particular country. Women are revered as an epitome of sacrifice and power in India. But when it comes to entrusting power into their hands. There is a hesitation from the male counterparts, as it poses a serious concern of overpowering their strengths and abilities. Women has excelled in all fields but her presence in politics makes the majority apprehensive. The reasons for this outlook can be contributed to the dominance of women in the area which is by and large become the Man's territory.

The focus of this paper is women in urban local level governance. The author in this paper wishes to concentrate on the urban local bodies and the impact of the $33 \%$ reservation on the participation of the women in the local level politics. She also wishes to delineate the barriers of political participation. However, women remain seriously underrepresented in decision-making positions. The central objective of this study is to examine challenges and opportunities of women political participation in urban local bodies.
\end{abstract}

Copy Right, IJAR, 2019,. All rights reserved.

\section{Introduction:-}

Women were from ages the nurturer, but what help can it do, when she cannot use her abilities to change the world. She had a lot of struggle to come to par with her masculine counterpart. But she is high on her emotional intelligence, the reason behind her excellence in all fields. But can our gendered society accept her empowerment? She is pushed into the dark and is incapacitated. Politics has become a man's word and Man's world. But in India, we have witnessed women rulers who were known for their righteous and transformational leadership from the ancient times up to the present. The success of the historical women send shivers down the spine of the men. They contemplated empowerment to women but relegated political empowerment to their pockets. They saw politics as a means to meet the desirable ends. Political vote banks was what they sought for. The autonomy granted in this area will be a hurdle to their victorious reign in the political arena.

\section{Participation of Women in Post Independent Period}

The foundation of political participation of women was laid down during the national movement. The transfer of power from British to Indian hand gave women opportunity to participate in democratic process. Large number of legal, social and economic measures has been taken up by the Independent government to raise the status of women

Corresponding Author:-Shashi kiran shetty.

Address:-Assistant Professor\& Head, Dept. Of Social Work, Acharya Institute of Graduate Studies \& 
in India. Women too have become politically conscious, as they have started participating in national and state politics.

Women participation in politics is pivotal to the social, economic and democratic growth of any nation. That is why it pertinent to embrace all forms of positive measures that will stimulate as well as sustain women's interest in political participation. One of these ways is implementation of quota allotment reserved for women. The problem of making laws and not implementing them is affecting virtually all sectors and this has also fast-tracked underdevelopment for women in politics. It is important that percentages seats in government as recommended by different notable bodies be adopted and thoroughly implemented.

In addition, to sustain women's participation in politics, there is the need for unparallel training and retraining with a unique innovative approach to impact knowledge and equip them with required resources for optimal productivity. With knowledge comes power and information for liberation; information cutting across all spheres of political participation, to motivate, support and encourage. This social sensitization should be extended to the general public as it would correct various stereotypic notions that could cause retrogression in women political participation, Civil city organisations are caught in the web of encouraging and equipping women to participate in politics.

In the same vein, active grooming and mentoring will go a long way in advancing women political participation and representation. Proper coaching and orientation would birth attitudinal change in women and break them from the patriarchal shackles imposed by the society. Some women are definitely interested in contributing their quota of proper representation in governance but they need concrete escapism to stay above the social limitations. Therefore, a mentorship scheme would position them in the right perspective to achieving this feat.

This 74th Amendment of the Indian Constitution ushered in a new era in the democratic process in India. It not only provided constitutional status to the municipal bodies but also provided an enabling environment for women to take part directly in the process of local self governmence It brought women to the forefront of city development. The 74th CAA has laid foundations for the emergence of strong bottom up women leadership who could climb the ladder to occupy positions of power at the state and national levels. Our country saw an increase in the number of EWR's in comparison with the previous years.

It is often easier for women to participate in local than at the national level, because of the flexibile eligibility criterias and the local government is the closest to the women's sphere of life, and easier to combine with rearing children. It serves as a springboard to national politics, by developing capacities and gaining experiences. Local level politics can be more interesting to women as they are well acquainted with their community,

\section{The line of Argument for Women's Political Participation}

Politics by and large has become a man's world. There are has been different arguments to assert her participation in the political sphere. The justice argument implies that women constituting half the population and their participation in politics is justified. The experience argument states that women's experiences differs from the men and needs representation result in policy-making and implementation. Women's perception of the needs and priorities are different from men. They may be sometimes conflicting and therefore women are needed to represent the institutions to express the interests of women. The symbolic argument states that every female politician acts a role model for all women, regardless of political views or party membership. She plays the role of the motivator to attract more women to the political arena. The critical mass argument states that women are able to achieve harmony of purpose to represent women's interests when they are able to achieve certain levels of representation .The democracy argument asserts that the equal representation of women and men enhances the democratization of governance in both transitional and consolidated democracies. All of the arguments deals about the importance of women inclusion in politics are justified.

\section{Barriers to Women's participation in politics}

These include:

\section{(a) Fundamental Inequality}

While women are bestowed with the constitutional rights they are not seen as equal, their roles are limited to their reproductive and household activities,. Politics and community affairs are seen as incompatible for them. In many countries women face obstacles such as culture and tradition (the view that men are superior to women), religion, political turmoil, violence, money, workloads and lack of opportunities. Demographic statistics, particularly in the 
South Asia subregion, show low literacy rates, poor health rates and poverty, all of which point to a lack of basic rights to such things as education, health care, safety and employment opportunities.

\section{(b) Political and Economic Instability}

Political and economic instability has a bearing on the development of a democratic political culture. Socioeconomic norms and religious norms are frequently used for challenging and women's rights and preventing women from participating in politics. Highly patriarchal societies dictate rules, responsibilities and behaviour for women, enforcing these norms in ways that lower their self-confidence, limiting their access to information and skills and reinforcing their lower status.

\section{(c) Discrimination}

Women encounter discrimination when contesting elections and when they are appointed to local government positions. Stereotyped perceptions of the role of women in governance undermine the governance capabilities of women.

\section{(d) The Male Environment within Political Institutions}

While there are few women on decision-making bodies, the working styles are unacceptable to men.. This sets boundaries for women to raise women's issues and issues of social justice. Some also find that they are judged harshly by society and by their colleagues.

\section{(e) Costs}

Campaign expenses pose a huge burden to women particularly if they do not have the necessary financial independence and lack the support from friends, family and the parties. Once elected, the honorarium in some countries can be meagre which does not in any way justify almost a full time job. The family care responsibilities and the timings of the important decisive meetings can clash at times. The money and time factor can be a hurdle to the active participation of women in local level politics.

\section{Conclusion:-}

There is a range of factors that hinder women's access to political participation in India. Despite the legal constitutional provisions, women are still at the subordinate position and women in the country occupy low status in the society. The involvement of women in policy formulation and decision making processes has been insignificant. Democracy has become a fundamental tool for accomplishing sustainable development. Political participation which is the manifestation of democracy allows for diversity of opinion and participation of both men and women cannot thrive by excluding the women folk that constitute half of the world's population. Without equal participation of women to political process, the hope for democracy and democratization is unrealisable. Thus, the democratic process is able to grow and develop effectively only when women can experience benefits equally with their counter parts. The active participation of women on par with with men at all levels of decision-making is essential to the achievement of equality, sustainable development, democracy and gendered governance.

\section{References:-}

1. Gidudu H,Enose, M, Betty T (2014)Socio-cultural Factors that Hinder Women's Access to Management Positions in Government Grant Aided Secondary Schools in Uganda: The Case of Eastern Region. International Research Journals 5: 241-250.

2. Handbook on Increasing Women's Political Participation in Georgia Tbilisi,(2014)

3. Melesse A, Ojulu O (2014) Assessment of Gender Equality in Ethiopia: The Position of Ethiopian Women's Political Representation from the World, Sub-Saharan Africa , and Eastern Africa Ethiopian Civil Service University. Journal of Law, Policy and Globalization.

4. Status of Women in urban local bodies of Rajasthan(2010), Shiv Charan Mathur, Social Policy Research Institute.

5. Leacock, E (1977), 'Reflection on Conference on Women and Development'. In Women and National Development: The Complexity of Change, Wellesley Editorial Committee, pp.320-22. Chicago, University of Chicago Press

6. EGM (2005) Equal Participation ofWomen and Men in Decision-Making Processes, with Particular Emphasis on Political Participation and Leadership. 